\title{
LIFE EXPECTANCY AND SOCIAL SECURITY: WHY LONGEVITY INDEXING THE PAYROLL TAX RATE MAKES GOOD ECONOMIC SENSE
}

\begin{abstract}
This paper examines the economic case for indexing the payroll tax to longevity. Over time, such a measure raises significant amounts of revenue, and can contribute to closing the existing actuarial shortfall in the trust fund. It makes common sense in that longer retirements call for additional funding. From a microeconomic standpoint, it preserves the special inter-generational benefit of social security whereby each generation participates in the higher productivity of the next. Most importantly, it has significant macroeconomic benefits in that it improves the matching of payments into the trust fund with payments out, thereby avoiding the deflationary bias that accompanies pre-funding while at the same time ensuring actuarial balance.
\end{abstract}

Key words: Social security, payroll tax, longevity indexing.

JEL ref.: E6

Thomas I. Palley

Assistant Director of Public Policy, AFL-CIO

Washington, D.C. 20006 


\section{Introduction}

The future of social security is under debate. Though there are widespread disagreements about the scale of the trust fund's future financial shortfall, all agree that a shortfall will materialize at some future date. According to the social security trustees (who have been accused of undue economic pessimism), the fund has sufficient total income and accumulated financial assets to fully cover benefits until 2032. Thereafter, given current funding arrangements, contribution income will only cover approximately $70 \%$ of promised benefits.

This projected shortfall has prompted calls for privatizing social security. The proposal is that individuals be allowed to set up private retirement accounts funded by part or all of their social security payroll tax contributions.

There are two important features about the privatization debate. First, the claims of those supporting privatization are marked by "bait and switch." Privatization is supposed to provide an identical product to that provided by social security, only cheaper. However, the reality is that privatization schemes fail to provide a guaranteed inflation-proof pension that lasts as long as one lives. In addition, they fail to provide either disability income insurance or income insurance for dependents of those suffering accidental death. Once the cost of providing these benefits are factored in, privatization is unable to match social security.

A second feature of the debate is the failure to recognize the special economic characteristics of social security. Social security has tended to be treated as if it were analogous to a private pension arrangement, the only difference being that social security is run by the government rather than Wall Street. However, social security is a special institutional arrangement that can realize inter-generational risk and income sharing outcomes that are unavailable in private markets. If 
these advantages are to be preserved, social security must be funded in accordance with the economics of public pensions rather than the economics of private pensions.

In this article I argue that longevity indexing of the social security payroll tax is an important mechanism for accomplishing this. It makes good economic sense by preserving social security in accordance with its inter-generational logic, and it makes good common sense because increased life expectancy is a primary cause of the shortfall. Most importantly, it has significant macroeconomic benefits in that it matches payments into the fund with payments out. It therefore contributes to actuarial balance but avoids the deflationary dangers associated with pre-funding.

\section{What is longevity indexing?}

Longevity indexing links the social security payroll tax rate to life expectancy. In a recently released study, Dean Baker (1998) of the Economic Policy Institute has proposed that the social security payroll tax rate be indexed to longevity. According to Baker, increasing the social security payroll tax rate by 0.02 percent points each year would close $64 \%$ of the existing projected trust fund shortfall, which stands at $2.19 \%$ of payroll. Given the current payroll tax rate, the rate paid by workers would rise from 6.2\% in 1998 to 6.4\% in 2008, and reach 7.4\% in 2058 .

Baker's suggestion details how longevity indexing can contribute to closing the trust fund shortfall, but as yet the economic case for such indexing remains to be made. It transpires that longevity indexing fits neatly with the underlying economics of social security. Moreover, not only does it have great economic sense, it also has great common sense in that it goes to the quick of the problem afflicting social security.

That problem is that life expectancy is gradually increasing so that people are enjoying longer retirements. Whereas this is a blessing for each of us individually, it poses a financial problem for 
social security which must pay out increased retirement benefits. Most existing remedies for social security's financial shortfall raise the retirement age. They therefore fix the financial problem, but only by robbing us of the blessing of a longer retirement. Contrastingly, longevity indexing can contribute to solving social security's financial problem while also allowing people to enjoy a longer retirement. Moreover, it has an additional economic advantage in that it matches saving and consumption streams, thereby avoiding the deflationary impact of excessive saving. For these reasons, longevity indexing offers the prospect of a win - win fix for social security.

\section{Longevity indexing and the micro economics of public pensions}

If people are living longer and spending more time in retirement, common sense dictates a need to put aside more to provide for a longer retirement. In a private pension scheme, individuals would either have to save more which is equivalent to raising the payroll tax rate, or take a cut in the value of retirement benefits. They could also delay their retirement and work and save slightly longer, thereby increasing their retirement nest egg. These are the options dictated by the economics of private pensions.

Such thinking has led many economists to recommend fixing social security through a combination of raised retirement age and reduced benefits. However, social security is not a private pension scheme, and those who advocate imposing the logic of private pension schemes fundamentally misunderstand the economics of social security. In doing so, they would significantly reduce social security's economic advantages over private pensions.

Social security is fundamentally different from a private pension scheme because it is an inter-generational arrangement whereby each working generation pays for the retirement of the previous generation. This inter-generational transfer structure has today's workers paying for 
today's retirees, and in return today's workers are promised a payment by tomorrow's workers, many of whom who are as yet unborn. Thus, social security payments in 2030 to retired baby boomers will in part derive from contributions made by young workers in 2030. Such an arrangement is impossible in private markets because it is not possible to contract with those who are legal minors today or those who are as yet unborn. Only government can enforce such an inter-generational compact through an arrangement such as social security. This means that social security can realize possibilities for inter-generational income and risk sharing that are unavailable in private pension arrangements.

In doing so, social security enables each generation to live at a slightly higher standard of living than would otherwise be possible. This is because wages are linked to labor productivity, and they therefore rise over time as productivity increases. Social security enables today's workers, when they are retired, to participate in the good fortune of tomorrow's workers, thereby raising their standard of living. All gain: yesterday's workers benefit from receiving a transfer from today's higher productivity workers, while today's workers benefit in future by receiving a future transfer from tomorrow's higher productivity workers, and so on. In this fashion, each generation is able to share in the greater productivity of the next, thereby enabling each to enjoy a higher standard of living.

If generations were of equal size, then the size of the inter-generational transfer would remain fixed over time. However, the greying of America implies that the elderly are becoming an increasing share of the population. This means that sharing the benefits of future productivity growth with current retirees requires a larger transfer from those currently working. Longevity indexing of the payroll tax rate automatically accomplishes this by having the size of the transfer 
rise as increased life expectancy raises the number of retirees. Those working today pay a little more to fund the increase in numbers of retirees, but they benefit in turn because they will live longer and be supported by future workers, and so on. As long as productivity continues to rise, longevity indexing can ensure that each generation shares in the bounty of higher future productivity. Each generation of working families can therefore enjoy the benefit of a longer retirement without being forced to reduce current consumption.

\section{The macroeconomics of longevity indexing: avoiding fiscal deflation}

Not only does longevity indexing fit with the underlying micro economics of the inter-generational compact that is the foundation of social security's economic advantage, but it also has macroeconomic advantages. In particular, it can help match contributions into the trust fund with payments out of the fund, thereby avoiding the deflationary danger of excessive national saving.

Social security has increasingly become a pre-funded retirement plan whereby the trust fund accumulates funds in anticipation of future payouts. Until the early 1980s social security was a de facto pay-as-you-go (PAYG) fund, with receipts immediately being paid out as benefits. However, as a result of the Greenspan Commission's (1983) recommendation to raise social security contributions, it has become partially pre-funded with the trust fund accumulating a surplus that is invested in government bonds. Most existing plans to remedy social security's financial shortfall aim to increase the extent of pre-funding by raising contributions, thereby building up a larger surplus. Such pre-funding would drain income from households, and risks reducing aggregate demand and economic activity.

Whether or not pre-funding is desirable turns on the question of whether increased saving 
stimulates or contracts economic activity. This is a long standing debate in economics (Palley, 1998). Supporters of pre-funding maintain that increased saving finds its way back into the economy through increased investment by firms. They argue that increased household saving will drive down interest rates and increase stock market prices, which will spur increased investment spending.

Opponents argue that increased saving may lower total demand, and thereby lower overall economic activity. While it is true that increased saving may lower interest rates and raise stock prices, thereby providing a spur to some additional investment, it is also true that increased household saving lowers consumption spending. The fall in consumption spending then results in excess capacity which reduces the incentive to invest. Moreover, empirical studies show that investment is not very sensitive to interest rates and stock market prices (Blanchard et al., 1993; Mork et al, 1990), while it is very sensitive to the level of demand and the degree of capacity utilization (Clark, 1979). As a result, increased saving can actually reduce investment despite lowering interest rates. In this scenario, increased saving brought about by increased pre-funding of social security could reduce both investment spending and consumption spending, thereby exerting a significant deflationary impact on the economy. This deflationary impact would continue as long as the trust fund ran surpluses, and would only reverse when the fund started paying out more than it was taking in.

Excessive pre-funding represents a deflationary danger. The real underlying economic problem posed by the greying of America is how to ensure that future retirees have sufficient future income without depressing current economic activity. The microeconomic logic of private pensions suggests that individuals should increase their individual saving, and this logic is now 
being foisted on social security through moves to increase the degree of pre-funding. However, there is a fallacy of composition: when all try to save, this depresses demand and drives down economic activity.

Viewed from this perspective, the problem is one of matching contributions into the retirement plan with payments out. Longevity indexing helps accomplish such matching of payments. As life spans increase, longevity indexing of the payroll tax rate ensures that more funds are gradually paid into the trust fund. At the same time, increasing life spans imply an increase in the size of the retiree population, which means that the trust fund will be paying out more retirement benefits that will be spent on consumption by the elderly. In this fashion, longevity indexing can address the macroeconomic problem of matching saving by the young with consumption by the elderly, while simultaneously addressing the distributional problem of ensuring that retirees have an appropriate amount of income.

\section{Common sense: preparing social security for the greying of America}

People are living longer. In 1997 female life expectancy at birth was 79.3 years, while that of males was 72.9 years; in 2075 female life expectancy is anticipated to be 84.2 years, while that of males is expected to be 79.3 years. In 1997, female life expectancy at age 65 was 19.2 years, while that of men was 15.6 years: in 2075 , the former is expected to be 22.2 years, while the latter is expected to be 18.8 years. This corresponds to a $20 \%$ increase in average length of retirement.

At the individual level, living longer is a boon. However, for the social security system it poses a financial problem since the trust fund must now pay out more to cover longer retirements. Absent an increase in the retirement age, a cut in retirement benefits, or an increase in payroll taxes paid in to the trust fund, increased longevity must inevitably result in a financial shortfall. 
The above observations are significant because they reveal how increased longevity is a principle cause of social security's financial difficulties. Much has been made of the baby boom's retirement, but the substantive problem is the on-going "greying of America" which will increase the number of retirees relative to the number of working age persons.

This trend will continue long after the baby boomers are deceased, and its effects already are visible in existing trust fund financial projections. According to the 1998 trustees' report the trust fund is fully solvent until 2032. At this time, surviving members of the leading edge of the baby boom (born in 1945) will be 87, while the youngest surviving members (born in 1964) will be 68. The bulk of the baby boom will therefore be well into their retirement. Excluding trust fund interest income, the annual shortfall in 2032 is projected to be 1.79\% of GDP. By 2050 it will rise to $1.87 \%$ of GDP, and by 2075 it will be $2.26 \%$ of GDP. At this date, baby boomers will have been long dead. The baby boom is not the problem: the greying of America is.

This historical process of increasing longevity stands to continue, and it implies that social security's shortfall will worsen as the projection period is extended further forward. A lasting solution must therefore link social security's finances with the underlying source of increased demands upon the system. Longevity indexing does this by linking social security's finances to life expectancy.

The Greenspan Commission of 1983 was supposed to have put social security on a permanently sound footing, yet less than fifteen years later social security again faces a shortfall. There is a danger that if the current debate does not permanently fix social security, then the public will eventually come to believe that it is unfixable. The greying of America means that social security faces further likely financial deterioration owing to underlying demographic conditions. This will 
result in increased shortfalls as the projection period is extended further forward. Restoring solvency to social security on the basis of the current projection period may therefore prove a temporary salve, in which case debate over the soundness of social security could re-emerge a few years hence. In that case, there is a danger that the public comes to believe social security to be unworkable, and social security's opponents could end up winning by attrition.

Longevity indexing guards against this by ensuring that contributions to the trust fund automatically rise with longevity. The big disadvantage is that such indexing of tax rates could be painted by opponents of social security as a tax increase. On the other hand, indexing has clear common sense appeal: if people are living longer, then we need to raise more revenues to cover their longer retirement, and what better way to do so than to link contributions to retirement duration. Furthermore, though tax rates do rise, the increase in rates is deferred well into the future when people will be much better off owing to higher wages resulting from higher productivity. According to the 1998 social security trustees' report, real wages are predicted to rise by $0.9 \%$ per year in the future. Fifty years from now real wages will have risen by $56.5 \%$ over today's level. Meanwhile, under longevity indexing the social security tax rate levied on workers will only have risen from $6.2 \%$ to $7.2 \%$. Thus, instead of being $56.5 \%$ better off than current workers, future workers will only be $55.5 \%$ better off. This is hardly a great loss, but today's workers will have been spared a raising of the retirement age or an increase in payroll taxes. This provides vivid proof of how social security's unique inter-generational compact can enhance societal well-being.

In sum, longevity indexing of the social security payroll tax rate appeals to common sense, and it is also good from the standpoint of both micro and macro economics. The one drawback is that the payroll tax is regressive, but this can be remedied by removing the income cap on social 
security contributions, or by structuring the payroll tax such that marginal rates rise with income. 


\section{References}

Baker, D, "Social Security: Problems and Solutions," Economic Policy Institute, Washington, D.C., 1998.

Blanchard, O., Rhee, C., and Summers, L., “The Stock Market, Profit, and Investment,” Quarterly Journal of Economics, 98 (1993), 115 - 36.

Clark, P., “Investment in the 1970s: Theory, Performance, and Prediction,” Brookings Papers on Economic Activity, 1 (1979), 73 - 124.

Mork, R., Shleifer, A., and Vishny, R., "The Stock Market and Investment: Is the Market a Sideshow?" Brookings Papers on Economic Activity, 2 (1990), 157-215.

Palley, T.I., "The Economics of Social Security: an Old Keynesian Perspective," Journal of Post Keynesian Economics, 21 (1998a), 93-110. 